\title{
DEVELOPMENT EVOLUTION OF THE ENVIRONMENTAL RISK MANAGEMENT THEORY: A META-ANALYSIS
}

\author{
Olena Korobets, Olena Chygryn, Maryna Saienko, and Liliia Liulova
}

\begin{abstract}
Due to the continuing trends of emergencies, the attention to solving the environmental risk problems has not lost its relevance for research in various fields. Changes in the development of the modern economy encourage the search for new methods of influencing environmental risks. Therefore, the relevance of the research topic is caused by looking for interrelated perspective directions of future research. In recent decades, the work of many scientists has been devoted to the environmental risks study. The growth of publishing activity has allowed accumulating a significant database, the consideration of which with the help of bibliometric analysis methods can help to identify new areas of research. The article provides a bibliometric analysis of the "environmental risk" concepts. The use of bibliometric data analysis tools allows working with a large number of publications, which makes it possible to identify research trends that are difficult to achieve without using special tools. For the analysis, the frequency dynamics of searching "environmental risk" in the Google search engine and the dynamics of publication activity on this concept in the scientometric database Scopus, for the period of 2004-2019 were determined. On the basis of selected publications with the help of VOSviewer software, visualization maps were constructed according to the selected concepts and their main points of intersection were determined. The results of the study revealed a decrease, but there exists stable attention to the problems of taking into account environmental risk in the economic entities' activity. The research method of the "ecological risk" concept from the point of view of its essence and structure is substantiated and described step by step.
\end{abstract}

Keywords: environmental risk, risk management, searching system, bibliometric analysis, pattern

JEL Classification: A30, M21, N50, P28 


\section{Authors:}

\section{Olena Korobets}

Sumy State University, 2 Rimski-Korsakov St., Sumy, Ukraine, 40007

E-mail:e.korobets@fem.sumdu.edu.ua

https://orcid.org/0000-0001-6977-4280

\section{Olena Chygryn}

Sumy State University, 2 Rimski-Korsakov St., Sumy, Ukraine, 40007

e-mail: o.chygryn@econ.sumdu.edu.ua

https://orcid.org/0000-0002-4007-3728

\section{Maryna Saienko}

Sumy State University, 2 Rimski-Korsakov St., Sumy, Ukraine, 40007

E-mail:m.saienko@kmm.sumdu.edu.ua

https://orcid.org/0000-0003-4939-6379

\section{Liliia Liulova}

Sumy State University, 2 Rimski-Korsakov St., Sumy, Ukraine, 40007

E-mail: I.lyulyuva@econ.sumdu.edu.ua

https://orcid.org/0000-0002-2912-722X

Citation: Korobets, O., Chygryn, O., Saienko, M., \& Liulova, L. (2020). Development Evolution of the Environmental Risk Management Theory: A Meta-Analysis. Virtual Economics, 3(4), 169-187. https://doi.org/10.34021/ve.2020.03.04(9) 


\section{Introduction}

In order to determine the most widely used term of environmental risk, the frequency of search "environmental risk", "ecological risk", "ecorisk", "green risk" in the Google search engine was analysed using the Google Trends tool. This application allows revealing the frequency of popularity search of a particular term in relation to the total volume of searches in different regions of the world. It should be noted that this tool has limitations in the data collection period, and starts from 2004.

The period from January 2004 to June 2020 was chosen for the study. The search for "ecological risk" and "ecorisk" contained a small amount of data for analysis, so they were not taken into account. The analysis results of the search frequency dynamics of the terms "environmental risk" and "green risk" are shown in Figure 1.

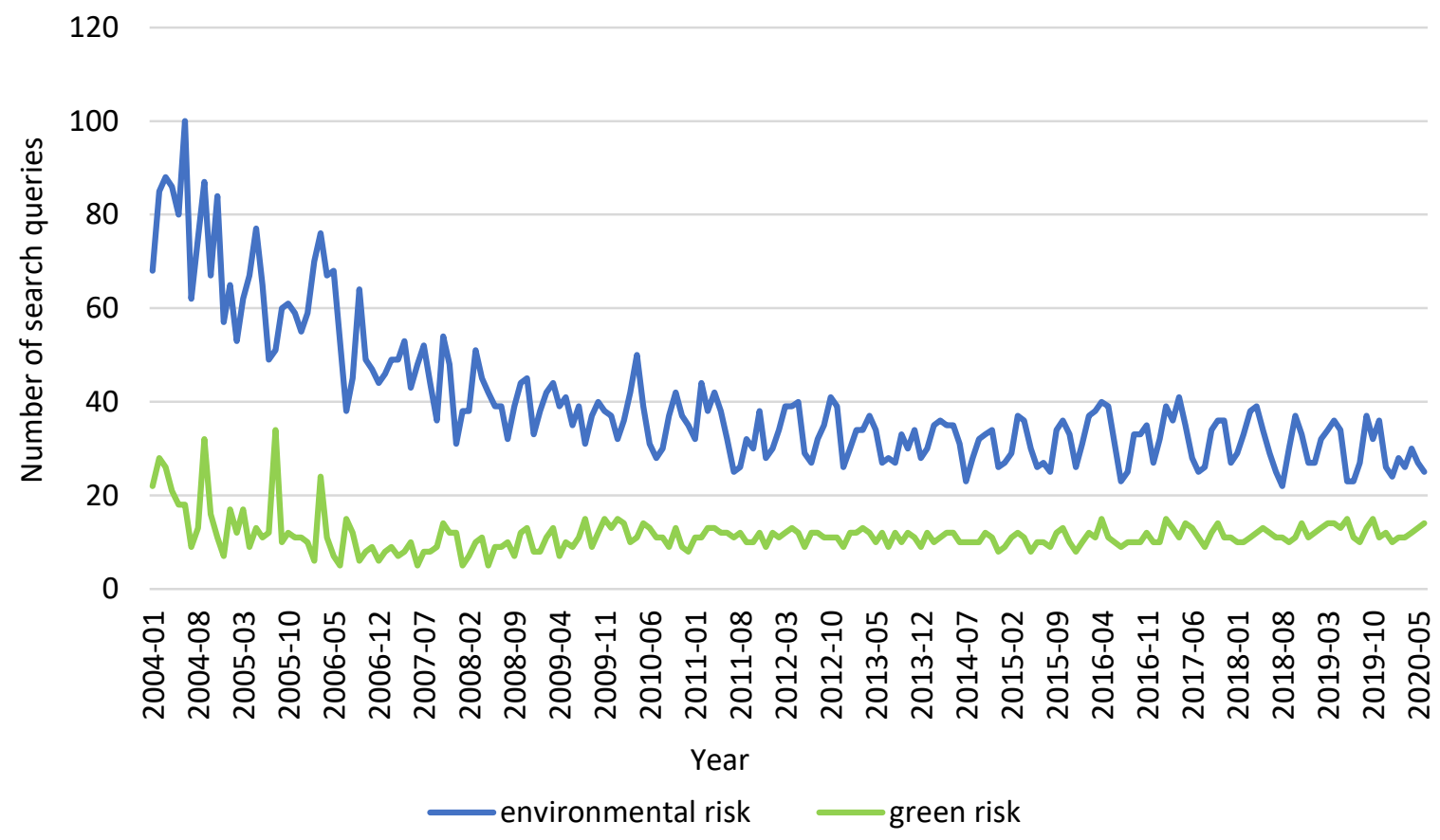

Figure 1. The Search for frequency dynamics of "environmental risk" and "green risk" in the search engines for the period of January 2005 - June 2020

Source: developed by the authors using the Google Trends tool.

The highest search activity in all terms is observed in the period from 2004 to 2006. Despite the decline in search dynamics since 2006, the trend has remained stable over the past 15 years.

Geographically, the intensity of using the above terms is distributed as follows: the term "environmental risk" is used when searching in Asian countries by $36.6 \%$, Africa - $30.2 \%$, Europe - $12.8 \%$, Oceania - 12.2\%, North America - 7.9\%, South America. The term "green risk" 
is used in European countries by $34.31 \%$, North America - $22.42 \%$, Oceania - $16.57 \%$, Asia $14.62 \%$, and Africa - $12.09 \%$.

At the same time, a number of searches were noted that accompany the selected terms for analysis and are searched in parallel with them. Thus, for the term "environmental risk" the most popular related searches comprise environmental risk assessment (100), risk assessment (99), environmental assessment (98), environmental risk management (56), environmental management (55), risk management (55), environmental factors (52), environmental health (52), risk factors (52), environmental risk factors (52), which means this term is aimed at identifying and managing risks. The term "green risk" is accompanied by risk management (100), green tea (67), risk assessment (60), green book (25), green revolution (12), blue green algae (10), green banking (9), green bay packers (9), blue green algae health risk (6), benefits of green tea (6). In this case, the term is aimed more at reducing the risks of final consumption of products produced using environmentally friendly technologies.

The analysis indicates the relevance of further study of the environmental risk management evolution, and a more detailed bibliometric analysis.

\section{The Literature Review}

In order to study the main trends in the evolution of the environmental risk management theory, a bibliometric analysis of research on this issue was carried out.

The results of the scientific literature systematization give us grounds to conclude that the word "risk" comes from the Arabic word "risk", or the Latin "risiqum". The first means something that is given by higher powers and with which you can benefit, the second is related to the challenge that a reef may pose to a sailor. Initially the concept of risk was expressed in two general meanings: as an action that will lead to a positive result, or as a possibility of danger, failure, loss (Picou \& Marshall, 2002; Pimoenenko et al., 2018a, Prothero \& Fitchett, 2002; Taranyuk, 2014; Tepman, 2002; Vasilyeva et al., 2018). However, a review of the literature on risk issues shows that there is no consensus among researchers on the definition of environmental risk and no a clear understanding of the nature of risk. This is explained, in particular, by the multifaceted nature of this phenomenon and ignoring it in real economic practice and management.

Analysing the literature on risk, we can identify a number of definitions of the "environmental risk". Risk has played a major role throughout the human history, as everyone who started a new business was at risk (Burkov et al., 2008; Hyett, 2010; Kachinskij, 2001; Karayeva et al., 2013, Kozmenko, 2008; Pimoenenko et al., 2018b). But the first risks described in history were, firstly, voluntary and, secondly, individual.

According to U. Beck (Beck, 2000), the meaning of "risk" in modern conditions has changed. In the new industrial environment, the nature and society are in danger that deprive risk of its individual nature, and environmental risks become global. In addition, environmental risks are 
increasingly difficult to understand and comprehend, because the essence of their action is hidden in chemical (toxins) or physical (electromagnetic fields) formulas.

There exist two states of risk:

1) risk as a possible future event that will lead to a certain result;

2) risk as a result that has already occurred.

The first definition is the cause of the risk, and the second is the result, as a consequence of the cause action (in the case of environmental risk analysis it is always negative). Risk serves as a link because it shows, on the one hand, an outcome that has not yet materialized and, on the other hand, selects potential damage. By its very nature, risk is an abstraction, that is, something that may or may not affect performance results.

Based on the above, risk is seen as a step-by-step process in which each stage allows an effective response to a step forward. There are several successive stages of environmental risk. It is often identified with the concept of danger, probability, and damage. Most authors (Pimonenko, 2019; McDonald et al., 2019; Yevdokimov et al., 2018; Abaas et al., 2018) define risk as a measure of these concepts. But it is necessary to take into account a significant difference in these terms.

To summarize a threat, it is an object that, under the influence of a certain factor or set of factors in a certain period of time, can cause damage. Threats underlie the cause of risk and form the first stage in the process of risk development. Stages of origin and development of an emergency situation are usually hidden and associated with accumulation of a destructive potential. At the climax, there are many dangerous and harmful factors that combine into one or more striking factors.

Having determined the list of threats and factors influencing them, we can proceed to the stage of determining the probability of their occurrence (Gordon et al., 2011; Chygryn et al., 2018; Belz \& Peattie, 2009; Lyulyov et al., 2018; Panchenko et al., 2020). Any event, under a certain set of conditions, corresponds to some degree of possibility. At the same time, it was noticed that more possible events at repeated research on the average come more often, and less possible ones come less often. A quantitative measure of the degree of an adverse event possibility is the probability of the event. The development functioning of many economic processes is characterized by situations that do not have a clear result or solution, so, the contributing factor of probability is uncertainty. Uncertainty means absence, incompleteness, inadequacy of information about an objects of threat, or a situation of risk in general, or presence of a high level of uncertainty in the accuracy of existing information. In the market economy, there are many sources of uncertainty for different economic entities (Kilbourne, 1998; Korobets et al., 2018; Us et al., 2019; Pimonenko et al., 2017; Peattie \& Crane, 2005; Menon \& Menon, 1997; Bogachov et al., 2020; Boiko et al., 2019; Czyżewski et al., 2019; Chygryn et al. 2020; Dalevska et al., 2019; Dementyev \& Kwilinski, 2020; Drozdz et al., 2019; 2020; Dzwigol, 2019a; 2019b; 2020a; 2020b; 2020c; Dzwigol \& Wolniak, 2018; Dzwigol \& Dźwigoł-Barosz, 2018; 2020; Dzwigol et al., 2019a; 2019b; 2019c; 2020a; Furmaniak 
et al., 2018; 2019a; 2019b; Kharazishvili et al., 2020; Kondratenko et al., 2020; Kuzior et al., 2020; Kwilinski, 2017; 2018a; 2018b; 2018c; 2018d; 2019; Kwilinski et al., 2019a; 2019b; 2019c; 2019d; 2019e; 2019f; 2019g; 2020a; 2020b; 2020c; 2020d; Kwilinski \& Kuzior, 2020; Kyrylov et al., 2020; Lakhno et al., 2018; Miskiewicz, 2017a; 2017b; 2018; 2020; Miśkiewicz \& Wolniak, 2020; Pająk et al., 2016; 2017; Prokopenko \& Miśkiewicz, 2020; Saługa et al., 2020; Savchenko et al., 2019; Tkachenko et al., 2019a; 2019b; 2019c; 2019d; 2019e; Yelnikova \& Miskiewicz, 2020).

To determine the degree of the environmental risk, the level of damage is important. Damage is realized through risk, acquiring specific shapes. We can say that this is a quantitative criterion of failure, which is considered as the final stage of the risk development process (Pimonenko et al., 2019; Rettie et al., 2012). The methodology for assessing the damage from various risks in the most complete form should include information about both direct and indirect damages. Direct damage in the case of environmental risk analysis is a direct impact on the environment in a short period of time, the consequences of which are immediate (rapid changes in air, soil, water, flora and fauna). Indirect damage arises as a result of implementing a certain action over a long period of time, but the consequences appear after a certain period (a gradual change in the indicators specified in the implementation of direct damage). As practice shows, indirect damage is often many times larger than direct one.

\section{Methods}

In this paper, based on the search analysis of "environmental risk" in the Google search engine, the relevance of the environmental risk management theory study is determined. In order to identify related areas of research that require more detailed study, with the help of bibliometric analysis, the main patterns of environmental risk research are formed. The method of bibliometric analysis is performed using VOSviewer software. It allows analysing the effectiveness of research and visualizing it. The Scopus scientometric database was selected for bibliometric analysis, on the basis of which the selection of publications was carried out using Scopus Tools (Korobets, 2020).

\section{Results and Discussion}

VOSviewer software was used to determine research patterns for economic risk. This program allows visualizing groups of major scientific trends based on the analysis of the keywords' occurrence frequency in the articles.

The study focused on publications indexed in the Scopus scientometric database. To identify the level of the research relevance in the scientific field, articles were selected on the keywords "environmental risk" and "green risk". According to the Scopus scientometric database, the first documents mentioning environmental risk appeared in 1946 in medical publications (Markman, B.J., Lewis, J.T.). A total of 138,602 publications were found. Since 1986 , there has been a clear growth dynamic of publications in various fields of knowledge. Currently, the largest share of publications is research in medicine $(27.8 \%)$, ecology $(24.5 \%)$, 
biochemistry, genetics and molecular biology (6.2\%), engineering (5.6\%), pharmacology, toxicology and pharmaceuticals (5.3\%). Economic directions of research are represented by 3282 publications (2.4\%). The dynamics of publishing activity over the past 20 years proves that the number of publications each year increases by an average of $8 \%$. Thus, if 414 articles were published in 1986, this figure amounted to 10,079 already in 2019. It was also noted that since 2000 , the growth rate of publications has increased sharply, averaging $9 \%$ per year.

When comparing the analysis results of the average value of search frequency of terms "environmental risk" and "green risk" in the Google search engine with the dynamics of publication activity for the period 2004-2019, a direct correlation of data was found (Table 1). The correlation coefficient indicated the presence of a medium or strong relationship with the value of 0.703 (limit value 0.7 ). This suggests that with the growth of publishing activity, interest in the concept of environmental risk in search engines grows as well.

In order to generate articles for bibliometric analysis, a selection of publications in the scientometric database Scopus was made. This selection was based on the established criteria: the language - English; keywords - "environmental risk", "green risk"; the period - 2004-2019; a document type - an article; areas of research - Business, Management and Accounting, Economics, Econometrics and Finance, Decision Sciences. Based on the selection, 1,791 articles were generated, making the basis for further analysis.

Table 1. The Relation between the Average Value of Search Frequency of Terms "Environmental Risk" and "Green Risk" in the Google Search Engine with the Dynamics of Publication Activity for the Period of 2004-2019.

\begin{tabular}{cccccc}
\hline Year & $\begin{array}{c}\text { Search } \\
\text { frequency in the } \\
\text { Google search } \\
\text { engine }\end{array}$ & $\begin{array}{c}\text { Dynamics of } \\
\text { publishing } \\
\text { activity }\end{array}$ & Year & $\begin{array}{c}\text { Search } \\
\text { frequency in the } \\
\text { Google search } \\
\text { engine }\end{array}$ & $\begin{array}{c}\text { Dynamics of } \\
\text { publishing } \\
\text { activity }\end{array}$ \\
\hline 2004 & 4,826 & 48.33 & 2012 & 7,096 & 22.75 \\
\hline 2005 & 4,788 & 37.21 & 2013 & 7,362 & 21.25 \\
\hline 2006 & 5,151 & 33.29 & 2014 & 7,752 & 21.08 \\
\hline 2007 & 5,359 & 27.15 & 2015 & 8,155 & 20.38 \\
\hline 2008 & 5,707 & 24.63 & 2016 & 8,348 & 21.75 \\
\hline 2009 & 5,778 & 24.75 & 2017 & 8,475 & 22.46 \\
\hline 2010 & 6,116 & 24.04 & 2018 & 9,111 & 21.33 \\
\hline 2011 & 6,862 & 22.54 & 2019 & 10,079 & 21.67 \\
\hline \multicolumn{7}{c}{ Correlation coefficient $=0.703$} \\
\hline
\end{tabular}

Source: compiled by the authors on the basis Google and Scopus.

The analysis allowed clustering the international research networks on the theory of environmental risk management by a geographical area (Figure 2). The largest number of 
publications on this issue was published by scientists from the United States, China, Britain, Canada and Germany. Patterns by geography were distributed as follows: pattern 1 - Great Britain, the Netherlands, Sweden, pattern 2 - the USA, Germany, France, Spain, pattern 3 Hong Kong, South Africa, Thailand, pattern 4 - Canada, Australia, pattern 5 - Italy, Japan, South Korea, pattern 6 - China, New Zealand.

Visualization of the research network allows identifying patterns of citation among scientists in the field of research (Figure 3).

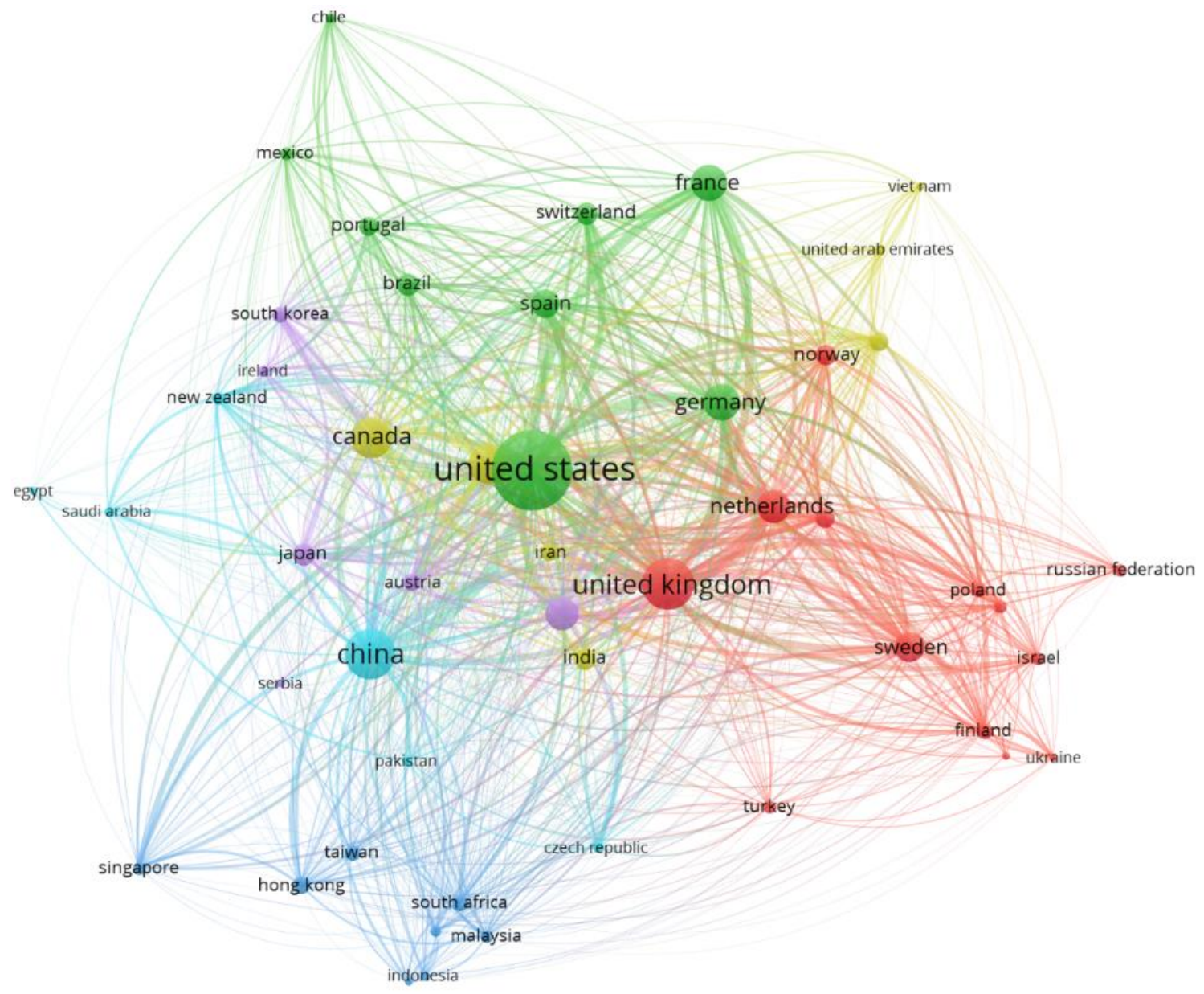

Figure 2. The Results of the Patterns Selection by a Geographical Location of International Research Networks Based on the Bibliometric Analysis of Scientific Papers on the Theory of Environmental Risk Management for 2004-2019.

Source: developed by the authors using the VOSviewer based on the Scopus database.

In general, there can be identified 6 main patterns of researchers studying the theory of environmental risk management by quoting each other and deepening the conceptual principles of risk management developed by their predecessors: pattern 1 - W. Zhang, L. Wang, 
W.W. Piegorch; pattern 2 - Y. Liu, J. Liu, Q. Wang, Y. Li; pattern 3 - J. Wang, Y. Yang, Z. Li; pattern 4 - A.P.J. Mol, Y. Lu; pattern 5 - Y. Wang, J. Wu, X. Zang; pattern 6 - G.H. Huang.

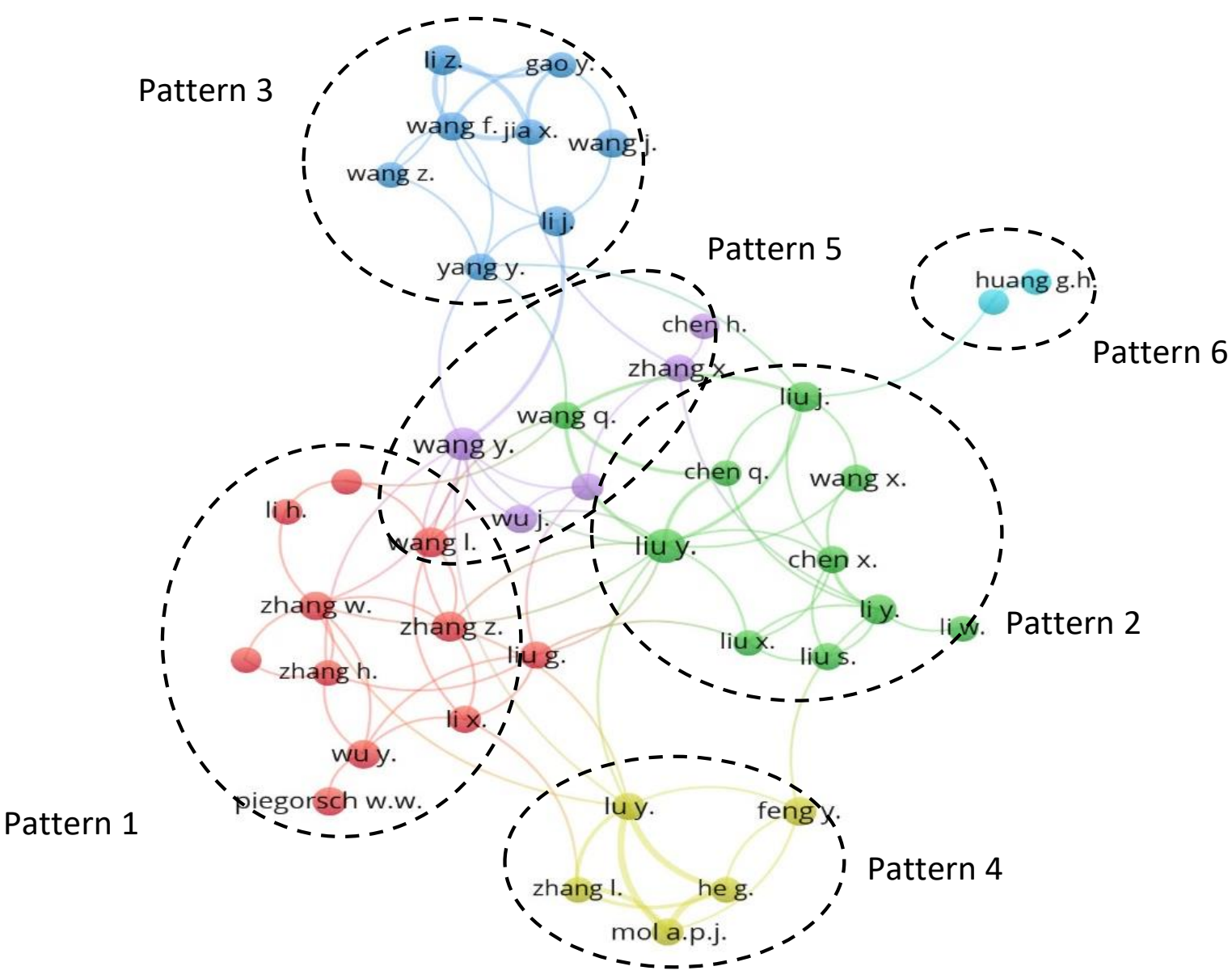

Figure 3. The Results of Identifying Scientists Whose Research Papers on Environmental Risk Management are Most Cited in Publications, Indexed by the Scientometric Database Scopus. Source: developed by the authors using the VOSviewer based on the Scopus database.

According to the results of the bibliographic analysis, 5 structural and functional patterns were formed that unite the key concepts on thematic proximity. The constructed visualization map (Figure 4) shows the frequency of the terms use (the size of the circle), the strength of the links between them (the closer, the stronger) and different combinations of terms both within clusters and among them.

The issues of environmental risk management are most often studied in close connection with the theories of the economic analysis (pattern 1), management theories (pattern 2), theories of nature management (pattern 3), theories of sustainable development (pattern 4), theories of production (pattern 5). 


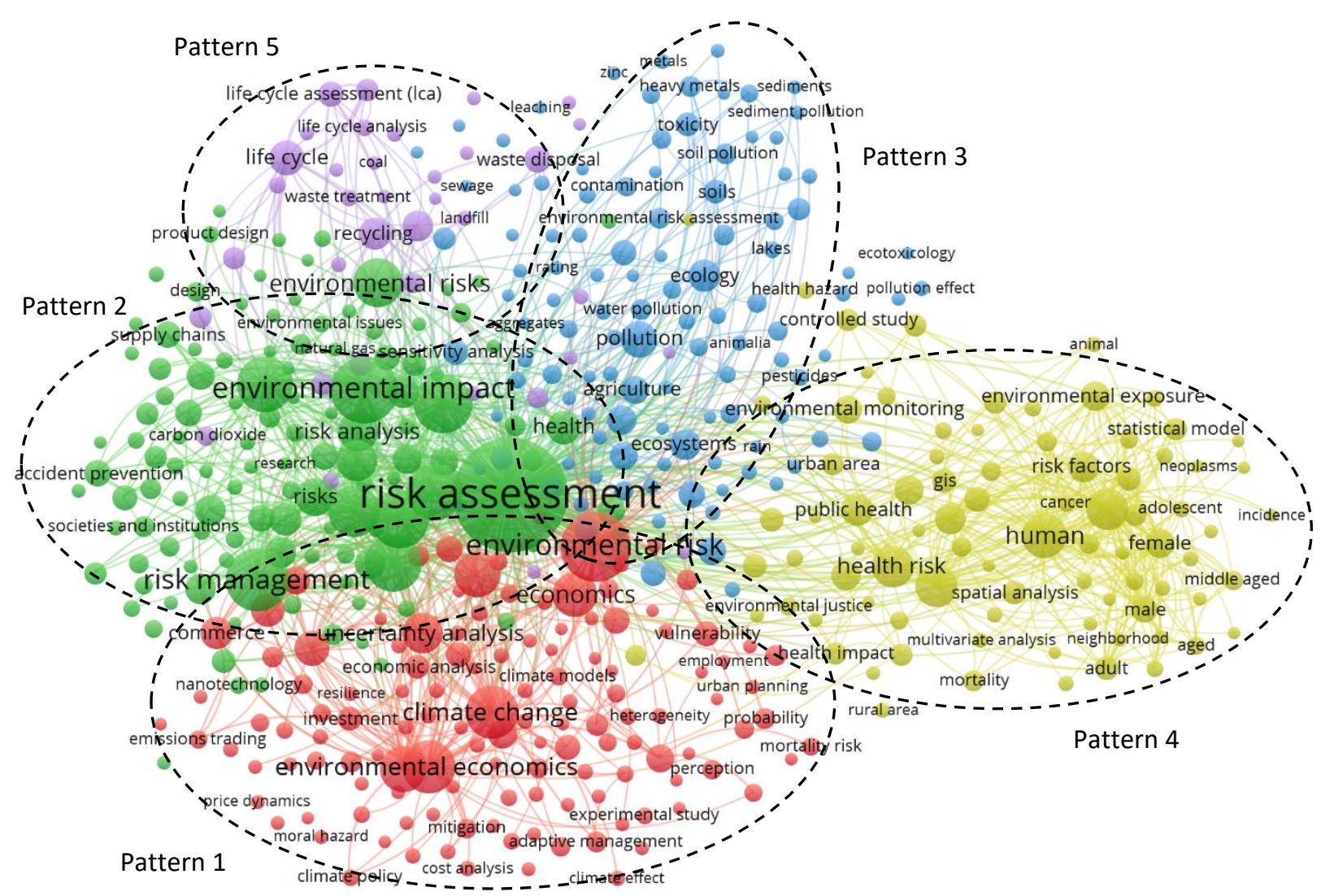

Figure 4. The Results of the Patterns Distribution by the Frequency of Key Phrases Use in Scientific Papers for 2004-2019.

Source: developed by the author using the VOSviewer based on the Scopus database.

The size of circles on figure 3 shows the frequency of using a particular term along with the concept of environmental risk. The largest is the red pattern (1). It includes assessment methods used in the analysis of the economic entities' impact on the environment. The green pattern (2) is the second largest. Here the key terms are: management, responsibility, strategic planning, efficiency, etc. They all relate to evaluating organizational activities and management effectiveness. The blue pattern (3) includes concepts related to climate change, agricultural land, water balance, assessment of sustainability and uncertainty, environmental policy, and so on. The yellow pattern (4) shows the set of objects and subjects of the natural environment that are affected: society, health, animals, land, air, water, forest, etc. It also includes assessment methods used to analyse such effects. Therefore, it is called "environment impact assessment". The purple pattern (5) is the second largest. In this cluster, the most common terms that are the outcome of the enterprise: pollution, waste, recycling, life cycle, and so on.

It has also been observed that the patterns of the economic analysis theory (1) and the production theory (5) have been actively followed since 2008. It is these studies that have given impetus to the development of other groups of patterns. 


\section{Conclusions}

Based on the study, the frequency of searches in search engines was determined using the Google Trends application. The highest search activity for the selected variants of the term was observed in the period 2004-2006. Despite the decrease in the search dynamics since 2007 , the trend has remained stable in recent years.

The analysis of publications that study aspects of environmental risk revealed 138,602 scientific articles in publications indexed by the Scopus scientometric database. The selection of publications according to the definite parameters (the language of a publication, keywords, the period of a publication, areas of research) allowed generating 1,791 articles for more detailed research.

The bibliometric analysis made it possible to identify 6 patterns of geographical location of international research networks that have mostly influenced the evolution of the theory of environmental risk management: pattern 1 - the UK, the Netherlands, Sweden, pattern 2 the USA, Germany, France, Spain, pattern 3 - Hong Kong, South Africa, Thailand, pattern 4 Canada, Australia, pattern 5 - Italy, Japan, South Korea, pattern 6 - China, New Zealand. Based on the analysis of citations, there were selected the most authoritative researchers and 6 research teams who significantly influenced the development of the theory of environmental risk management. The analysis results of the keywords frequency use identified 5 structural and functional patterns. It is found that the most common issues of environmental risk management are studied in close connection with the theories of economic analysis (pattern 1), management theories (pattern 2), theories of nature management (pattern 3), theories of sustainable development (pattern 4), theories of production (pattern 5).

\section{Formatting of Funding Sources}

This research was funded by the grant from the Ministry of Education and Science of Ukraine (№0120U102002).

\section{References}

Abaas, M. S. M., Chygryn, O., Kubatko, O., \& Pimonenko, T. (2018). Social and Economic Drivers of National Economic Development: The Case of OPEC Countries. Problems and Perspectives in Management, 4, 155-168. Retrieved from https://www.ceeol.com/search/articledetail?id $=712765$

Beck, W. (2000). Risk Society. On the Way to Another Art Nouveau. Moscow: Progress-Tradition.

Belz, F. M., \& Peattie, K. (2009). Sustainability Marketing: A Global Perspective. Chichester: Wiley. 
Bogachov, S., Kwilinski, A., Miethlich, B., Bartosova, V., Gurnak, A. (2020). Artificial Intelligence Components and Fuzzy Regulators in Entrepreneurship Development. Entrepreneurship and Sustainability Issues, 8(2), 487-499. http://doi.org/10.9770/jesi.2020.8.2(29)

Boiko, V., Kwilinski, A., Misiuk, M., \& Boiko, L. (2019). Competitive Advantages of Wholesale Markets of Agricultural Products as a Type of Entrepreneurial Activity: The Experience of Ukraine and Poland. Economic Annals-XXI, 175(1-2), 68-72. https://doi.org/10.21003/ea.V175-12

Burkov, V. N., Novikov, D. A., \& Shchepkin, A. V. (2008). Mekhanizmy upravleniya ekologoekonomicheskimi sistemami [Mechanisms for the management of environmental and economic systems]. Moscow: Fizmatlit. [in Russian].

Chygryn, O., Pimonenko, T., Luylyov, O., \& Goncharova, A. (2018). Green Bonds like the Incentive Instrument for Cleaner Production at the Government and Corporate Levels: Experience from EU to Ukraine. Journal of Environmental Management and Tourism, 9(7), 1443-1456.

Chygryn, O., Bilan, Y., \& Kwilinski, A. (2020). Stakeholders of Green Competitiveness: Innovative Approaches for Creating Communicative System. Marketing and Management of Innovations, 3, 356-368. https://doi.org/10.21272/mmi.2020.3-26

Czyżewski, B., Matuszczak, A., \& Miskiewicz, R. (2019). Public Goods Versus the Farm Price-Cost Squeeze: Shaping the Sustainability of the EU's Common Agricultural Policy. Technological and Economic Development of Economy, 25(1), 82-102. https://doi.org/10.3846/tede.2019.7449

Dalevska, N., Khobta, V., Kwilinski, A., \& Kravchenko, S. (2019). A Model for Estimating Social and Economic Indicators of Sustainable Development. Entrepreneurship and Sustainability Issues, 6(4), 1839-1860. https://doi.org/10.9770/jesi.2019.6.4(21)

Dementyev, V.V., \& Kwilinski, A. (2020). Institutsionalnaya sostavlyayuschaya izderzhek proizvodstva [An Institutional Component of Production Costs]. Journal of Institutional Studies, 12(1), 100-116. https://doi.org/10.17835/2076-6297.2020.12.1.100-116

Drozdz, W., Miskiewicz, R., Pokrzywniak, J., \& Elzanowski, F. (2019). Urban Electromobility in the Context of Industry 4.0. Torun: Wydawnictwo Adam Marszalek.

Drozdz, W., Marszalek-Kawa, J., Miskiewicz, R., \& Szczepanska-Waszczyna, K. (2020). Digital Economy in the Contemporary World. Torun: Wydawnictwo Adam Marszalek.

Dzwigol, H. (2019a). The Concept of the System Approach of the Enterprise Restructuring Process. Virtual Economics, 2(4), 46-70. https://doi.org/10.34021/ve.2019.02.04(3)

Dzwigol, H. (2019b). Research Methods and Techniques in New Management Trends: Research Results. Virtual Economics, 2(1), 31-48. https://doi.org/10.34021/ve.2019.02.01(2) 
Dzwigol, H. (2020a). Innovation in Marketing Research: Quantitative and Qualitative Analysis. Marketing and Management of Innovations, 1, 128-135. http://doi.org/10.21272/mmi.2020.1-10

Dzwigol, H. (2020b). Methodological and Empirical Platform of Triangulation in Strategic Management. Academy of Strategic Management Journal, 19(4), 1-8.

Dźwigoł, H. (2020c). Interim Management as a New Approach to the Company Management. Review of Business and Economics Studies, 8(1), 20-26. https://doi.org/10.26794/2308-944X-2020-8-1-2026

Dzwigol, H., \& Wolniak, R. (2018). Controlling w procesie zarządzania chemicznym przedsiębiorstwem produkcyjnym [Controlling in the Management Process of a Chemical Industry Production Company]. Przemys/ Chemiczny, 97(7), 1114-1116. https://doi.org/10.15199/62.2018.7.15

Dzwigol, H., \& Dźwigoł-Barosz, M. (2018). Scientific Research Methodology in Management Sciences. Financial and Credit Activity: Problems of Theory and Practice, 2(25), 424-437. https://doi.org/10.18371/fcaptp.v2i25.136508

Dzwigol, H., \& Dzwigol-Barosz, M. (2020). Sustainable Development of the Company on the Basis of Expert Assessment of the Investment Strategy. Academy of Strategic Management Journal, 19(5), 1-7.

Dzwigol, H., Shcherbak, S., Semikina, M., Vinichenko, O., \& Vasiuta, V. (2019a). Formation of Strategic Change Management System at an Enterprise. Academy of Strategic Management Journal, 18(SI1), 1-8.

Dzwigol, H., Aleinikova, O., Umanska, Y., Shmygol, N., \& Pushak, Y. (2019b). An Entrepreneurship Model for Assessing the Investment Attractiveness of Regions. Journal of Entrepreneurship Education, 22(1S), 1-7.

Dzwigoł, H., Dzwigoł-Barosz, M., Zhyvko, Z., Miskiewicz, R., \& Pushak, H. (2019c). Evaluation of the Energy Security as a Component of National Security of the Country. Journal of Security and Sustainability Issues, 8(3), 307-317. http://doi.org/10.9770/jssi.2019.8.3(2)

Dzwigol, H., Dźwigoł-Barosz, M., \& Kwilinski, A. (2020d). Formation of Global Competitive Enterprise Environment Based on Industry 4.0 Concept. International Journal of Entrepreneurship, 24(1), 1-5.

Dzwigol, H., Dzwigol-Barosz, M., Miskiewicz, R., \& Kwilinski, A. (2020). Manager Competency Assessment Model in the Conditions of Industry 4.0. Entrepreneurship and Sustainability Issues, 7(4), 2630-2644. https://doi.org/10.9770/jesi.2020.7.4(5)

Furmaniak, S., Gauden, P.A., Patrykiejew, A., Miśkiewicz, R., \& Kowalczyk, P. (2018). Carbon Nanohorns as Reaction Nanochambers - a Systematic Monte Carlo Study. Scientific Reports, 15407. https://doi.org/10.1038/s41598-018-33725-z 
Furmaniak, S., Gauden, P.A., Patrykiejew, A., Miskiewicz, R., \& Kowalczyk, P. (2019a). The Effects of Confinement in Pores Built of Folded Graphene Sheets on the Equilibrium of Nitrogen Monoxide Dimerisation Reaction. Journal of Physics Condensed Matter, 31(13), 135001, 1-12. https://doi.org/10.1088/1361-648X/aaffb3

Furmaniak, S., Gauden, P.A., Patrykiejew, A., Szymański, G., Miśkiewicz, R., \& Kowalczyk, P. (2019b). In Silico Study on the Effects of Carbonyl Groups on Chemical Equilibrium of Reactions with a Polar Product Occurring under Confinement in Pores of Activated Carbons. Chemical Engineering Communications, 1-12. https://doi.org/10.1080/00986445.2019.1700115

Gordon, R., Carrigan, M., \& Hastings, G. (2011). A Framework for Sustainable Marketing. Marketing Theory, 11(2), 143-163.

Hyett, D. (2010,). Environmental Risk Assessment in Environmental Impact Assessment-Optional or Mandatory? In IAIA10 Conference Proceedings: The Role of Impact Assessment in Transitioning to the Green Economy. 30th Annual Meeting of the International Association for Impact Assessment. 6-11.

Kachinskij, A. B. (2001). Ekologichna bezpeka Ukrainy: sistemnyi analiz perspektiv pokrashchennia [Ecological Security of Ukraine: A Systematic Analysis of Prospects for Improvement]. Kyiv: NISD.

Karayeva, N. V., Vojtko, S. V., \& Sorokina, L. V. (2013). Ryzyk-menedzhment stalogo rozvytku energetyky: informatsijna pidtrymka prijnyattya rishen [Risk-Management of Steel Energy Development: Information Technology Training]. Retrieved from https://www.voytko.kpi.in.ua. [in Ukrainian].

Kharazishvili, Y., Kwilinski, A., Grishnova, O., \& Dzwigol, H. (2020). Social Safety of Society for Developing Countries to Meet Sustainable Development Standards: Indicators, Level, Strategic Benchmarks (with Calculations Based on the Case Study of Ukraine). Sustainability, 12(21), 8953. https://doi.org/10.3390/su12218953

Kilbourne, W. E. (1998). Green Marketing: A Theoretical Perspective. Journal of Marketing Management, 14(6), 641-655.

Kondratenko, V., Okopnyk, O., Ziganto, L., \& Kwilinski, A. (2020). Innovation Development of Public Administration: Management and Legislation Features. Marketing and Management of Innovations, 1, 87-94. https://doi.org/10.21272/mmi.2020.1-06

Korobets, O. M., Slavkova, O. P., \& Shynkarenko, M. M. (2018). Analysis of the Macroeconomic Stability Indicators Changing Dynamics in Ukraine. Mechanism of Economic Regulation, 4, 127-134.

Korobets, O. M. (2020). Bibliometrychnyi analiz vzaiemozviazku ponyat' "ekolohichnyi ryzyk" ta "marketynh" [Bibliometric Analysis of Relation between the Concepts of "Marketing" and 
"Environmental Risk"]. Scientific bulletin of Polissia, 1(20), 104-110. http://doi.org/10.25140/24109576-2020-2-1(20)-104-110 [in Ukrainian].

Kozmenko, O. V. (2008). Strakhovyi rynok Ukrainy u konteksti stalogo rozvytku [Ukraine's Insurance Market in the Context of Sustainable Development]. Sumy: DVNZ "UABS NBU". [in Ukrainian].

Kuzior, A., Kwilinski, A., \& Tkachenko, V. (2019). Sustainable Development of Organizations Based on the Combinatorial Model of Artificial Intelligence. Entrepreneurship and Sustainability, 7(2), 13531376. http://doi.org/10.9770/jesi.2019.7.2(39)

Kwilinski, A. (2017). Development of Industrial Enterprise in the Conditions of Formation of Information Economics. Thai Science Review, Autumn 2017, 85-90. https://doi.org/10.5281/zenodo.1414236

Kwilinski, A. (2018a). Mechanism of Formation of Industrial Enterprise Development Strategy in the Information Economy. Virtual Economics, 1(1), 7-25. https://doi.org/10.34021/ve.2018.01.01(1)

Kwilinski, A. (2018b). Mechanism of Modernization of Industrial Sphere of Industrial Enterprise in Accordance with Requirements of the Information Economy. Marketing and Management of Innovations, 4, 116-128. http://doi.org/10.21272/mmi.2018.4-11

Kwilinski, A. (2018c). Mechanism for Assessing the Competitiveness of an Industrial Enterprise in the Information Economy. Research Papers in Economics and Finance, 3(1), 7-16. https://doi.org/10.18559/ref.2018.1.1

Kwilinski, A. (2018d). Trends of Development of the Information Economy of Ukraine in the Context of Ensuring the Communicative Component of Industrial Enterprises. Economics and Management, 1(77), 64-70.

Kwilinski, A. (2019). Implementation of Blockchain Technology in Accounting Sphere. Academy of Accounting and Financial Studies Journal, 23(SI2), 1-6.

Kwilinski, A., Tkachenko, V., \& Kuzior, A. (2019a). Transparent Cognitive Technologies to Ensure Sustainable Society Development. Journal of Security and Sustainability Issues, 9(2), 561-570 http://doi.org/10.9770/jssi.2019.9.2(15)

Kwilinski, A., Drobyazko, S., \& Derevyanko, B. (2019b). Synergetic and Value Effects in Corporate Mergers and Acquisitions of International Companies. In Khalid S. Soliman (Ed.), Proceedings of the 34th International Business Information Management Association Conference (IBIMA) 13-14 November 2019. Vision 2025: Education Excellence and Management of Innovations through Sustainable Economic Competitive Advantage in 2019 (pp. 9467-9471). Madrid, Spain: IBIMA Publishing.

Kwilinski, A., Dalevska, N., Kravchenko, S., Hroznyi, I., Kovalenko, I. (2019c). Formation of the Entrepreneurship Model of E-Business in the Context of the Introduction of Information and 
Communication Technologies. Journal of Entrepreneurship Education, 22(SI1), 1528-2651-22-S1337: 1-7.

Kwilinski, A., Ruzhytskyi, I., Patlachuk, V., Patlachuk, O., \& Kaminska, B. (2019d). Environmental Taxes as a Condition of Business Responsibility in the Conditions of Sustainable Development. Journal of Legal, Ethical and Regulatory Issues, 22(SI2) 1544-0044-22-SI-2-354: 1-6.

Kwilinski, A., Volynets, R., Berdnik, I., Holovko, M., \& Berzin, P. (2019e). E-Commerce: Concept and Legal Regulation in Modern Economic Conditions. Journal of Legal, Ethical and Regulatory Issues, 22(SI2), 1544-0044-22-SI-2-357: 1-6.

Kwilinski, A., Dzwigol, H., \& Dementyev, V. (2019f). Transnational Corporations as Entities of International Entrepreneurship. International Journal of Entrepreneurship, 23(SI4), 1-6.

Kwilinski, A., Pajak, K., Halachenko, O., Vasylchak, S., Pushak, Ya., \& Kuzior, P. (2019g). Marketing Tools for Improving Enterprise Performance in the Context of Social and Economic Security of the State: Innovative Approaches to Assessment. Marketing and Management of Innovations, 4, 172-181. http://doi.org/10.21272/mmi.2019.4-14

Kwilinski, A., \& Kuzior, A. (2020). Cognitive Technologies in the Management and Formation of Directions of the Priority Development of Industrial Enterprises. Management Systems in Production Engineering, 28(2), 119-123. http://doi.org/10.1515/mspe-2019-0020

Kwilinski, A., Vyshnevskyi, O., \& Dzwigol, H. (2020a). Digitalization of the EU Economies and People at Risk of Poverty or Social Exclusion. Journal of Risk and Financial Management, 13(7), 142. https://doi.org/10.3390/jrfm13070142

Kwilinski, A., Zaloznova, Y., Trushkina, N., \& Rynkevych, N. (2020b). Organizational and Methodological Support for Ukrainian Coal Enterprises Marketing Activity Improvement. E3S Web of Conferences, 168, 00031. https://doi.org/10.1051/e3sconf/202016800031

Kwilinski, A., Dielini, M., Mazuryk, O., Filippov, V., \& Kitseliuk, V. (2020c). System Constructs for the Investment Security of a Country. Journal of Security and Sustainability Issues, 10(1), 345-358. https://doi.org/10.9770/jssi.2020.10.1(25)

Kwilinski, A., Shteingauz, D., \& Maslov, V. (2020). Financial and Credit Instruments for Ensuring Effective Functioning of the Residential Real Estate Market. Financial and Credit Activities: Problems of Theory and Practice. 3(34), 133-140. Retrieved from https://fkd.ubs.edu.ua/index.php/fkd/article/view/3023

Kyrylov, Y., Hranovska, V., Boiko, V., Kwilinski, A., \& Boiko, L. (2020). International Tourism Development in the Context of Increasing Globalization Risks: On the Example of Ukraine's Integration into the Global Tourism Industry. Journal of Risk and Financial Management, 13(12), 303. https://doi.org/10.3390/jrfm13120303 
Lakhno, V., Malyukov, V., Bochulia, T., Hipters, Z., Kwilinski, A., \& Tomashevska, O. (2018). Model of Managing of the Procedure of Mutual Financial Investing in Information Technologies and Smart City Systems. International Journal of Civil Engineering and Technology, 9(8), 1802-1812.

Lyulyov, O., Chygryn, O., \& Pimonenko, T. (2018). National Brand as a Marketing Determinant of Macroeconomic Stability. Marketing and Management of Innovations, 3, 142-152. http://doi.org/10.21272/mmi.2018.3-12

McDonald, S., Oates, C. J., Alevizou, P. J., Young, C. W., \& Hwang, K. (2012). Individual Strategies for Sustainable Consumption. Journal of Marketing Management, 28(3-4), 445-468.

Menon, A., \& Menon, A. (1997). Enviropreneurial Marketing Strategy: The Emergence of Corporate Environmentalism as Market Strategy. The Journal of Marketing, 61(1), 51-67.

Miskiewicz, R. (2017a). Knowledge in the Process of Enterprise Acquisition. Progress in Economic Sciences, 4, 415-432. https://doi.org/10.14595/PES/04/029

Miskiewicz, R. (2017b). Knowledge Transfer in Merger and Acquisition Processes in the Metallurgical Industry. Warsaw: PWN.

Miskiewicz, R. (2018). The Importance of Knowledge Transfer on the Energy Market. Polityka Energetyczna, 21(2), 49-62. http://dx.doi.org/10.24425\%2F122774

Miskiewicz, R. (2019). Challenges Facing Management Practice in the Light of Industry 4.0: The Example of Poland. Virtual Economics, 2(2), 37-47. https://doi.org/10.34021/ve.2019.02.02(2)

Miskiewicz, R. (2020). Internet of Things in Marketing: Bibliometric Analysis. Marketing and Management of Innovations, 3, 371-381. http://doi.org/10.21272/mmi.2020.3-27

Miskiewicz, R. (2020a). Efficiency of Electricity Production Technology from Post-Process Gas Heat: Ecological, Economic and Social Benefits. Energies, 13(22), 6106. https://doi.org/10.3390/en13226106

Miśkiewicz, R, \& Wolniak, R. (2020b). Practical Application of the Industry 4.0 Concept in a Steel Company. Sustainability, 12(14), 5776. https://doi.org/10.3390/su12145776

Pająk, K., Kamińska, B., \& Kvilinskyi, O. (2016). Modern Trends of Financial Sector Development under the Virtual Regionalization Conditions. Financial and Credit Activity: Problems of Theory and Practice, 2(21), 204-217. https://doi.org/10.18371/fcaptp.v2i21.91052

Pająk, K., Kvilinskyi, O., Fasiecka, O., \& Miskiewicz, R. (2017). Energy Security in Regional Policy in Wielkopolska Region of Poland. Economics and Environment, 2(61), 122-138.

Panchenko, V., Harust, Y. V., Us, Y. O., Korobets, O. M., \& Pavlyk, V. V. (2020). Energy-Efficient Innovations: Marketing, Management and Law Supporting. Marketing and Management of Innovations, 1, 256-264. http://doi.org/10.21272/mmi.2020.1-21 
Peattie, K., \& Crane, A. (2005). Green Marketing: Legend, Myth, Farce or Prophesy? Qualitative Market Research: An International Journal, 8(4), 357-370.

Picou, J. S., \& Marshall, B. K. (2002). Contemporary Conceptions of Environmental Risk: Implications for Resource Management and Policy. Sociological Practice, 4(4), 293-313.

Pimoenenko, T., Chyhryn, O., \& Liulov, O. (2018a). Green Entrepreneurship as an Integral Part of the National Economy Convergence. National Security \& Innovation Activities: Methodology. Policy and Practice: A monograph. Sumy, Ukraine: SSU.

Pimonenko, T. (2019). A Conceptual Framework for Development of Ukraine's Green Stock Market. Herald of Ternopil National Economic University, 4(90), 69-80.

Pimonenko, T., Lyulyov, O., Chygryn, O., \& Palienko, M. (2018b). Environmental Performance Index: relation between social and economic welfare of the countries. Environmental Economics, 9(3), 1.

Pimonenko, T., Lyulyov, O., \& Us, Y. (2019). Green Development of Small and Medium Enterprises of Ukraine: the EU experience. In Conference: Conferința "Competitivitatea şi Inovarea în Economia Cunoaşterii", 1, 69-78.

Pimonenko, T., Lyulyova, L., \& Us, Y. (2017). Energy-Efficient House: Economic, Ecological and Social Justification in Ukrainian Conditions. Environmental economics, 8(4), 53-61.

Prokopenko, O., \& Miśkiewicz, R. (2020). Perception of "Green Shipping" in the Contemporary Conditions. Entrepreneurship and Sustainability Issues, 8(2), 269-284. https://doi.org/10.9770/jesi.2020.8.2(16)

Prothero, A., \& Fitchett, J. A. (2000). Greening Capitalism: Opportunities for a Green Commodity. Journal of Macromarketing, 20(1), 46-55.

Rettie, R., Burchell, K., \& Riley, D. (2012). Normalising Green Behaviours: A New Approach to Sustainability Marketing. Journal of Marketing Management, 28(3-4), 420-444.

Saługa, P.W., Szczepańska-Woszczyna, K., Miśkiewicz, R., \& Chłąd, M. (2020). Cost of Equity of CoalFired Power Generation Projects in Poland: Its Importance for the Management of DecisionMaking Process. Energies, 13(18), 4833.https://doi.org/10.3390/en13184833

Savchenko, T., Basiurkina, N., Rodina, O., \& Kwilinski, A. (2019). Improvement of the Assessment Methods of Product Competitiveness of the Specialized Poultry Enterprises. Management Theory and Studies for Rural Business and Infrastructure Development, 41(1), 43-61. https://doi.org/10.15544/mts.2019.05

Taranyuk, K. V. (2014). Organizaczijno-ekonomichni osnovi upravlinnya ekologichnim rizikom na regionalnomu rivni [Organizational-Economic Fundamentals of Environmental Management of the Region on the Regional Level]: dis. Sumy: SumDU. 
Tepman, L. N. (2002). Riski v ekonomike [Risks in the Economy]. Moscow: YuNITI-DANA.

Tkachenko, V., Kwilinski, A., Korystin, O., Svyrydiuk, N., \& Tkachenko, I. (2019a). Assessment of Information Technologies Influence on Financial Security of Economy. Journal of Security and Sustainability, 8(3), 375-385. http://doi.org/10.9770/jssi.2019.8.3(7)

Tkachenko, V., Kwilinski, A., Klymchuk, M., \& Tkachenko, I. (2019b). The Economic-Mathematical Development of Buildings Construction Model Optimization on the Basis of Digital Economy. Management Systems in Production Engineering, 27(2), 119-123. http://doi.org/10.1515/mspe2019-0020

Tkachenko, V., Kwilinski, A., Tkachenko, I., \& Puzyrova, P. (2019c). Theoretical and Methodical Approaches to the Definition of Marketing Risks Management Concept at Industrial Enterprises. Marketing and Management of Innovations, 2, 228-238. http://doi.org/10.21272/mmi.2019.2-20

Tkachenko, V., Kwilinski, A., Kaminska, B., Tkachenko, I., \& Puzyrova, P. (2019d). Development and Effectiveness of Financial Potential Management of Enterprises in Modern Conditions. Financial and Credit Activity: Problems of Theory and Practice, 3(30), 85-94. https://doi.org/10.18371/fcaptp.v3i30.179513

Tkachenko, V., Kuzior, A., \& Kwilinski, A. (2019e). Introduction of Artificial Intelligence Tools into the Training Methods of Entrepreneurship Activities. Journal of Entrepreneurship Education, 22(6), 110.

Us, Y. O., Liuta, O. V., Vasylieva, T. A., \& Kyrychenko, K. I. (2019). Public Integrity Index: The Visegrad Countries' Experience. SumDU Bulletin: Economics Serie, 2, 132-137.

Vasilyeva, T., Lyeonov, S., Lyulyov, O., \& Kyrychenko, K. (2018). Macroeconomic Stability and Its Impact on the Economic Growth of the Country. Montenegrin Journal of Economics, 14(1), 159-170.

Yelnikova, Y., \& Miskiewicz, R. (2020). Implementation Mechanism of Impact Investing in the PostConflict Regions. Financial Markets. Institutions and Risks, 4(3), 53-65.

https://doi.org/10.21272/fmir.4(3).53-62.2020

Yevdokimov, Y., Chygryn, O., Pimonenko, T., \& Lyulyov, O. (2018). Biogas as an Alternative Energy Resource for Ukrainian Companies: EU experience. Innovation Marketing, 14, 7-15. 